\title{
Respon Pertumbuhan dan Hasil Tanaman Padi Sawah akibat Aplikasi Blue Green Algae dan Pupuk N
}

\author{
Mieke R. Setiawati dan Pujawati Suryatmana \\ Departemen Ilmu Tanah dan Sumberdaya Lahan, Fakultas Pertanian Universitas Padjadjaran \\ Jl. Raya Bandung Sumedang Km 21 Jatinangor \\ Korespondensi: m.setiawati@unpad.ac.id
}

\begin{abstract}
The growth and yield of rice plants is very dependent on nitrogen $(N)$ fertilizer. $N$ fertilizer applied to wetland rice mostly unutilized due to the lost through the process of denitrification and leaching. The presence of blue-green algae (BGA), procaryotic algae $N_{2}$-fixing in the paddy field is advantageous to help to uptake the $N$ for plants by direct fixation of $N_{2}$ from air and then converted into cell proteins. Excess $N$ fixation results were released into the BGA growth environment. BGA biomass at the latter stage will be mineralized to ammonium. Mineralized ammonium from BGA cells as a source of $N$ that can be used directly by paddy plants. This experiment used a randomized block design with factorial pattern; BGA inoculant dose treatment consisted of: $0 ; 5 \mathrm{~kg} ; 10 \mathrm{~kg} \mathrm{ha}^{-1}$ and urea

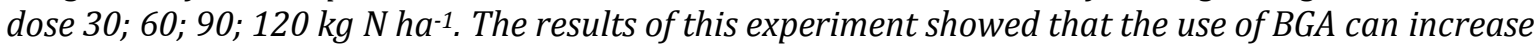
the rate of growth of rice plants and reduced urea requirements by $25 \%$. The combination of $90 \mathrm{~kg}$ $\mathrm{ha}^{-1} \mathrm{~N}$ fertilizer with $10 \mathrm{~kg} \mathrm{ha}^{-1}$ Blue-green algae inoculant can increase grain yield by $31.47 \%$ per hectare (2.71 tons $\mathrm{ha}^{-1}$ ).
\end{abstract}

Keyword: Nitrogen fertilizer, BGA, paddy plant, reduce urea

\section{PENDAHULUAN}

Defisiensi unsur hara yang paling berpengaruh terhadap produksi tanaman adalah nitrogen. Nitrogen (N) adalah unsur utama yang penting bagi tanaman, unsur tersebut dibatasi oleh kandungan dan ketersediaannya yang rendah. Nitrogen merupakan input utama pada usaha pertanian tanaman padi, akan tetapi harga pupuk nitrogen relatif mahal untuk produksi tanaman padi, sehingga perlu dicari alternatif lain dalam menanggulangi masalah tersebut. Penambahan unsur tersebut melalui pemupukan dapat meningkatkan kandungan unsur tersebut akan tetapi ketersediaannya rendah untuk dapat diserap tanaman. Pupuk $\mathrm{N}$ yang diberikan sebagian besar dapat hilang melalui proses pencucian dan volatilisasi akibat reaksi denitrifikasi. Pemberian pupuk yang cenderung meningkat akibat respon tanaman yang rendah menyebabkan pemborosan yang tidak perlu. Untuk menanggulangi masalah tersebut kita dapat memanfaatkan mikroba tanah yang dapat menambat $\mathrm{N}_{2}$ dari udara sebagai sumber pupuk $\mathrm{N}$ yang ramah lingkungan.
Atmosfer merupakan sumber nitrogen berlimpah dalam bentuk gas $\mathrm{N}_{2}$. Gas $\mathrm{N}_{2}$ terdapat sekitar $78 \%$ dari volume atmosfer. Hanya tanaman legum yang dapat memanfaatkan sumber $\mathrm{N}$ yang berlimpah ini melalui aktivitas bakteri penambat $\mathrm{N}_{2}$. Selain itu tanaman non legum masih dapat memanfaatkan sumber $\mathrm{N}$ tersebut melalui pemanfaatan Blue Green Algae (BGA). Alternatif yang dapat diambil untuk mengatasi kelangkaan pupuk $\mathrm{N}$ dan kebutuhannya yang semakin meningkat dengan menggali potensi mikroorganisme dari jenis sianobakteria penambat $\mathrm{N}_{2}$. Mengingat di alam terutama di daerah tropis seperti Indonesia, keragaman BGA sangat potensial untuk dikembangkan. BGA merupakan sumber nitrogen alternatif yang bersifat terbarukan (nonrenewable) dan ramah lingkungan.

BGA dalam sistematika terbaru masuk ke dalam golongan bakteri yang disebut sianobakteria yang dapat memfiksasi $\mathrm{N}_{2}$ dari udara. BGA tumbuh secara alami di tanah yang tergenang seperti ekosistem sawah yang merupakan tempat tumbuh tanaman padi. 
Menurut Gardner et. al. (2008), cyanobakteria dapat memfiksasi unsur hara nitrogen dan sianobakteria merupakan salah satu jenis bakteri hidup bebas yang dapat menyumbangkan nitrogen untuk ketersediaan nitrogen dalam tanah. Aktivitas fiksasi $\mathrm{N}_{2}$ oleh bakteri ini penting untuk keseimbangan nitrogen secara menyeluruh karena Nitrogen terfiksasi terus menerus dapat hilang karena denitrifikasi.

Tanaman padi merupakan tanaman pokok yang penting di Asia. Beras merupakan makanan pokok dalam pola makanan lebih dari $40 \%$ populasi penduduk di dunia sehingga merupakan tanaman pangan yang sangat penting untuk ditingkatkan produksinya (Stoltzfus et. al., 1997). Kebutuhan beras dimasa mendatang akan meningkat sesuai dengan tingkat perkembangan populasi penduduk. Pada dua puluh tahun terakhir ini diperkirakan kenaikannya lebih dari satu persen per tahun (Dawe, 2000). Untuk meningkatkan produksi tanaman padi, intensifikasi melalui pemberian pupuk $\mathrm{N}$ yang efisien masih memungkinkan dilakukan di Indonesia.

Pada skala rumah kaca substitusi pupuk $\mathrm{N}$ oleh BGA penambat $\mathrm{N}_{2}$ pada tanaman padi dapat ditentukan melalui inokulasi konsorsia blue-green algae penambat $\mathrm{N}_{2}$ pada tanaman padi yang ditanam pada media tanah sawah di dalam pot dengan dosis pupuk $\mathrm{N}$ dikurangi pada berbagai taraf dari dosis anjuran. Dosis anjuran pupuk $\mathrm{N}$ untuk padi adalah $120 \mathrm{~kg} \mathrm{~N}$ ha $^{-1}$ (Deptan, 1996). Dengan adanya suplai $\mathrm{N}$ hasil penambatan $\mathrm{N}_{2}$ dari udara oleh konsorsium BGA penambat $\mathrm{N}_{2}$ pada tanaman padi, kebutuhan pupuk $\mathrm{N}$ untuk pertumbuhan tanaman dapat dikurangi. Besarnya substitusi pupuk $\mathrm{N}$ pada padi tergantung dari kemampuan konsorsium sianobakteria tersebut dalam menambat $\mathrm{N}_{2}$. Kondisi tanah sawah menyediakan lingkungan yang menguntungkan bagi pertumbuhan BGA.

Menurut Subba Rao (1994), fiksasi nitrogen BGA pada sawah sekitar $49 \mathrm{~kg} \mathrm{ha}^{-1}$ dalam kondisi normal dan dapat menjadi dua kali lipat apabila tersedia sejumlah fosfat dan molibdenum secara optimum di dalam tanah. Selain memfiksasi nitrogen BGA juga mensintesis dan mengekskresikan beberapa vitamin dan zat tumbuh, auksin, dan asam askorbat yang menyebabkan pertumbuhan padi menjadi lebih baik. Misra dan Kaushik (1989); Kaushik, (2014) melaporkan bahwa peran BGA selain berkontribusi dalam menyediakan $\mathrm{N}$, senyawa pemicu partumbuhan yang dibebaskan oleh BGA juga memainkan peran penting dalam mempertahankan hasil panen. Sejumlah zat yang mendorong pertumbuhan tanaman antara lain asam amino, gula, polisakarida, vitamin B12, asam nikotinat, asam pantotenat, asam folat, hormon pertumbuhan IAA.

Aplikasi isolat unggul BGA yang telah teruji secara nyata dalam meningkatkan fiksasi nitrogen pada tanaman padi di sawah akan meningkatkan hasil gabah kering tanaman padi. Peningkatan hasil panen padi sawah dengan aplikasi inokulan BGA dapat mencapai 10,2 \% sampai 21,1 \%. Rata-rata peningkatan sekitar $300 \mathrm{~kg} \mathrm{ha}^{-1}$ gabah dengan inokulasi BGA atau dapat menghemat pupuk $\mathrm{N}$ sebesar $25 \mathrm{~kg} \mathrm{~N} \mathrm{ha}^{-1}$.

Menurut Rao (1994), penggunaan BGA pada padi sawah mampu mensuplai $30 \mathrm{~kg} \mathrm{~N}$ ha $^{-1}$. Dalam kultur murni blue-green algae (BGA) ini memfiksasi nitrogen sekitar 5,2 hingga $14,48 \mathrm{mg} / 100 \mathrm{ml}$ medium. Selain itu, BGA juga memiliki kemampuan mensintesis dan mengekskresi vitamin dan zat tumbuh seperti vitamin $B_{12}$, auksin dan asam askorbat yang menyebabkan pertumbuhan tanaman padi menjadi lebih baik. Menurut Roger and Kulasooriya (1980) penggunaan BGA di India dengan dosis $10 \mathrm{~kg} \mathrm{ha}^{-1}$ bersamaan dengan pupuk nitrogen mampu meningkatkan hasil padi sekitar $300 \mathrm{~kg} \mathrm{ha}^{-1}$.

Goyal (1993) menyatakan bahwa percobaan agronomi yang dilakukan dengan tanaman padi umumnya menunjukkan bahwa $\mathrm{N}$ yang disumbangkan oleh BGA berkisar 20$30 \mathrm{~kg} / \mathrm{ha}$. Dengan demikian, menggunakan BGA di sawah, petani dapat menghemat hingga $20-30 \mathrm{~kg} \mathrm{~N} /$ ha tanpa mengurangi hasil normal. Menurut (Chakdar et. al., 2012), 
Cyanobacteria juga dikenal dapat melarutkan dan memobilisasi fosfor (P) dan membuatnya tersedia untuk tanaman.

Menurut Donahue et. al. (1983), urea yang diberikan ke dalam tanah sebagai pupuk $\mathrm{N}$ akan mudah larut dan tercuci. Liat dan humus di dalam tanah akan mengikat $\mathrm{NH}_{4}$ (amonium) yang larut dari pupuk urea dalam bentuk amonium yang dapat ditukar sehingga mudah tersedia bagi tanaman. Pada kondisi yang lembab dan suhu yang hangat, urea dihidrolisis menjadi amonium karbonat dan oleh aktivitas bakteri nitrifikasi dalam tanah diubah menjadi nitrat dalam waktu kurang dari seminggu. Nitrogen dalam tanah umumnya ditemukan dalam bentuk $\mathrm{NO}_{3}{ }^{-}$ (nitrat). Amonium yang berasal dari pupuk di dalam tanah akan mengalami penurunan yang cepat diikuti dengan peningkatan nitrat yang cepat pula (De Datta, 1975).

Tujuan penelitian ini adalah menguji pemanfaatan BGA penambat $\mathrm{N}_{2}$ untuk meningkatkan efisiensi pemupukan $\mathrm{N}$ pada tanaman padi di lahan sawah. Diharapkan penghematan pemupukan urea di lahan sawah pada tanaman padi dapat ditanggulangi dengan asupan nitrogen dari hasil penambatan $\mathrm{N}_{2}$ dari udara oleh BGA.

\section{METODOLOGI}

Untuk mengetahui efektifitas BGA sebagai pupuk hayati pemasok $\mathrm{N}$ bagi tanaman padi, maka dilakukan uji efektifitas BGA. Uji efektifitas dilakukan pada skala Green House terhadap tanaman Padi. Percobaan ini menggunakan tanah sawah Inseptisol dengan berat $15 \mathrm{~kg}$ tanah kering udara per pot. Pengolahan tanah di dalam pot dilakukan seperti mengolah tanah sawah yaitu perendaman, pelumpuran, dan dikondisikan macak-macak.

Produksi inokulan BGA dilakukan pada tangki kultur yang dangkal yang diisi tanah sawah kering yang sudah disaring, pupuk SP$361 \%$, dan natrium molibdat $0.001 \%$. Tangki tersebut diisi dengan air setinggi $20 \mathrm{~cm}$. Isolat unggul BGA yang telah teruji kemampuannya dalam menambat $\mathrm{N}_{2}$ disebarkan di permukaannya. BGA dibiarkan tumbuh sampai 21 hari, setelah BGA tumbuh subur maka isi tangki dibiarkan mengering sampai terbentuk lempeng-lempeng kering dan disimpan dalam plastik polietilen sebagai inokulan.

Rancangan percobaan yang dilakukan dalam penelitian adalah Rancangan Acak Kelompok (RAK) pola faktorial dilakukan tiga ulangan, dengan perlakuan:

- Faktor pertama (B): dosis inokulan BGA, yang terdiri dari 3 taraf perlakukan yaitu: 0; $5 \mathrm{~kg}$; $10 \mathrm{~kg} \mathrm{ha}^{-1}$.

- Faktor kedua (N): dosis urea, yang terdiri dari 4 taraf perlakukan yaitu: 30 ; $60 ; 90 ; 120 \mathrm{~kg} \mathrm{~N} \mathrm{ha}^{-1}$.

\section{HASIL DAN PEMBAHASAN}

\subsection{Tinggi Tanaman Padi Sawah}

Hasil analisis statistik menunjukkan tidak terjadi interaksi antara perlakuan aplikasi Urea dengan BGA pada variasi dosis terhadap tinggi tanaman pada 1 minggu setelah tanam (MST), akan tetapi pemberian pupuk urea yang semakin meningkat dapat meningkatkan tinggi tanaman padi.

Tabel 1 Efek mandiri pupuk $\mathrm{N}$ dan inokulan BGA penambat $\mathrm{N}_{2}$ terhadap tinggi tanaman pada 1 MST

\begin{tabular}{cc}
\hline Perlakuan & $\begin{array}{c}\text { Rata-rata-tinggi } \\
\text { tanaman }(\mathrm{cm})\end{array}$ \\
\hline
\end{tabular}

$$
\begin{array}{cc}
\text { Pupuk Urea (N) } & \\
\mathrm{n}_{1}: 30 \mathrm{~kg} \mathrm{ha}^{-1} \mathrm{~N} & 15,10 \mathrm{a} \\
\mathrm{n}_{2}: 60 \mathrm{~kg} \mathrm{ha}^{-1} \mathrm{~N} & 15,88 \mathrm{ab} \\
\mathrm{n}_{3}: 90 \mathrm{~kg} \mathrm{ha}^{-1} \mathrm{~N} & 15,89 \mathrm{ab} \\
\mathrm{n}_{4}: 120 \mathrm{~kg} \mathrm{ha}^{-1} \mathrm{~N} & 16,67 \mathrm{~b} \\
\text { Inokulan BGA (B) } & \\
\mathrm{k}_{0} \text { : kontrol (BGA) } & 15,37 \mathrm{a} \\
\mathrm{k}_{1}: 5 \mathrm{~kg} \mathrm{ha}^{-1} \mathrm{BGA} & 15,55 \mathrm{a} \\
\mathrm{k}_{2}: 10 \mathrm{~kg} \mathrm{ha}^{-1} \mathrm{BGA} & 15,71 \mathrm{a}
\end{array}
$$

Keterangan : Angka-angka yang diikuti huruf yang sama tidak berbeda nyata menurut uji Jarak Berganda Duncan pada taraf 5 \% 
Pemberian pupuk nitrogen $120 \mathrm{~kg} \mathrm{ha}^{-1} \mathrm{~N}$ berpengaruh terhadap peningkatan tinggi tanaman dibandingkan dengan pemberian pupuk urea $30 \mathrm{~kg} \mathrm{ha}^{-1} \mathrm{~N}$ pada $1 \mathrm{MST}$. Hal ini karena pemberian pupuk $\mathrm{N}$ dengan dosis 120 $\mathrm{kg}$ ha $^{-1} \mathrm{~N}$ memberikan ketersedian unsur ammonium yang segera dapat dimanfaatkan untuk pertumbuhan tanaman padi. Menurut Novizan (2003) nitrogen dibutuhkan dalam jumlah relatif besar pada setiap tahap pertumbuhan tanaman, khususnya pada tahap pertumbuhan vegetatif, seperti pembentukan tunas atau perkembangan batang dan daun.

Tanaman yang kekurangan nitrogen maka pertumbuhannya lambat dan kerdil, memiliki perakaran yang terbatas, daun menjadi kuning atau hijau kekuningan dan akhirnya kering. Jipelos (1989) menjelaskan bahwa dalam praktek pemupukan, nitrogen yang diserap tanaman hanya berkisar antara 22-65 \%. Secara umum efisiensi serapan nitrogen pada lahan sawah beririgasi hanya bisa mencapai $45 \%$ dan sisanya sekitar 55\% tidak dapat dimanfaatkan tanaman. Oleh karena itu dosis pupuk $\mathrm{N}$ yang tinggi dapat memberikan pengaruh yang lebih nyata terhadap peningkatan tinggi tanaman padi sawah.

Efek mandiri pemberian inokulan BGA berbagai taraf dosis pada umur 1 MST tidak berpengaruh terhadap tinggi tanaman. Pada satu minggu setelah aplikasi BGA diduga sianobakteria tersebut masih menyesuaikan di lingkungan baru dan memperbanyak diri sebelum menyumbangkan unsur $\mathrm{N}$ ke sawah hasil penambatan $\mathrm{N}_{2}$ dari udara. Berdasarkan hasil penelitian Ghosh dan Saha (1993); Roger et. al. (1993) nitrogen yang difiksasi oleh Cyanobacteria dapat tersedia untuk tanaman padi hanya setelah dilepaskan secara ekstraseluler ke sekitarnya, baik sebagai produk ekstraseluler atau melalui mineralisasi kandungan intraselulernya melalui penguraian mikroba dari massa alga segar atau kering yang dibenamkan ke dalam tanah. Akan tetapi fiksasi oleh Cyanobacteria terus menerus pelepasannya dalam sistem air tanah diduga lebih bermanfaat untuk produksi tanaman selama tahap pertumbuhan vegetatif padi daripada tahap selanjutnya. Menurut Oren (2004) BGA dapat bereproduksi dengan pembelahan biner, yaitu pembelahan sel secara langsung. Dengan pembelahan sel, baik sel tunggal (organisme uniseluler) maupun sel penyusun filamen (benang) akan bertambah banyak. Filamen akan bertambah panjang karena adanya pembelahan sel. Perbanyakan BGA memerlukan waktu yang bervariasi tergantung dari jenis BGA dan faktor lingkungan.

Inokulasi BGA penambat $\mathrm{N}_{2}$ dengan pupuk $\mathrm{N}$ menghasilkan interaksi yang nyata ketika tanaman padi berumur 5 MST (Tabel 2). Hal ini disebabkan karena BGA sudah dapat beraktivitas dengan baik dalam penambat $\mathrm{N}_{2}$. Hasil analisis menunjukkan bahwa pupuk $\mathrm{N}$ berpengaruh nyata terhadap rata-rata tinggi tanaman, sedangkan inokulan BGA berperan sebagai pemberi pasokan $\mathrm{N}$ tambahan untuk tanaman padi sawah. Akibat adanya pasokan $\mathrm{N}$ dari inokulan BGA $10 \mathrm{~kg} \mathrm{ha}^{-1}$ maka dosis pupuk $\mathrm{N}$ yang dibutuhkan untuk meningkatkan tinggi tanaman padi menjadi berkurang yaitu $90 \mathrm{~kg} \mathrm{~N} \mathrm{ha}^{-1}$.

Tabel 2 Pengaruh interaksi pupuk $\mathrm{N}$ dan inokulan BGA penambat $\mathrm{N}_{2}$ terhadap rata-rata tinggi tanaman pada 5 MST

\begin{tabular}{|c|c|c|c|}
\hline \multirow{2}{*}{$\begin{array}{l}\text { Pupuk Urea } \\
\text { (n) }\end{array}$} & \multicolumn{3}{|c|}{ BGA (k) } \\
\hline & $\begin{array}{c}\text { Kontrol } \\
\left(\mathrm{k}_{0}\right)\end{array}$ & $\begin{array}{c}5 \mathrm{~kg} \mathrm{ha}^{-1} \\
\left(\mathrm{k}_{1}\right)\end{array}$ & $\begin{array}{c}10 \mathrm{~kg} \mathrm{ha}^{-1} \\
\left(\mathrm{k}_{2}\right)\end{array}$ \\
\hline $\begin{array}{c}30 \mathrm{~kg} \mathrm{~N} \mathrm{ha}^{-1} \\
\left(\mathrm{n}_{1}\right)\end{array}$ & $\begin{array}{c}56,70 \mathrm{a} \\
\mathrm{A}\end{array}$ & $\begin{array}{c}57,00 \mathrm{a} \\
\mathrm{A}\end{array}$ & $\begin{array}{c}53,70 \mathrm{a} \\
\mathrm{A}\end{array}$ \\
\hline $\begin{array}{c}60 \mathrm{~kg} \mathrm{~N} \mathrm{ha}^{-1} \\
\left(\mathrm{n}_{2}\right)\end{array}$ & $\begin{array}{c}58,30 \mathrm{ab} \\
\mathrm{A}\end{array}$ & $\begin{array}{c}59,13 \mathrm{a} \\
\mathrm{A}\end{array}$ & $\begin{array}{c}57,03 \mathrm{ab} \\
\mathrm{A}\end{array}$ \\
\hline $\begin{array}{c}90 \mathrm{~kg} \mathrm{~N} \mathrm{ha-1} \\
\left(\mathrm{n}_{3}\right)\end{array}$ & $\begin{array}{c}62,97 \mathrm{~b} \\
\mathrm{AB}\end{array}$ & $\begin{array}{c}58,83 \mathrm{a} \\
\mathrm{A}\end{array}$ & $\begin{array}{c}63,57 \mathrm{~b} \\
\mathrm{~B}\end{array}$ \\
\hline $\begin{array}{c}120 \mathrm{~kg} \mathrm{~N} \mathrm{ha-1} \\
\left(\mathrm{n}_{4}\right)\end{array}$ & $\begin{array}{c}61,43 a b \\
\text { B }\end{array}$ & $\begin{array}{c}55,60 \mathrm{a} \\
\mathrm{A}\end{array}$ & $\begin{array}{c}59,77 \mathrm{ab} \\
\mathrm{AB}\end{array}$ \\
\hline : & $\begin{array}{l}\text { a-angk } \\
\text { tidak } \\
\text { Berga } \\
\text { a yan } \\
\text { ca hor }\end{array}$ & $\begin{array}{l}g \text { diik } \\
\text { eda nya } \\
\text { Duncan } \\
\text { tandai } \\
\text { al dar }\end{array}$ & $\begin{array}{l}\text { taraf } 5 \% \text {, } \\
\text { taf kapital }\end{array}$ \\
\hline
\end{tabular}


Giller (2001) menyatakan bahwa BGA dapat mempengaruhi pertumbuhan tanaman padi. Peningkatan bobot tajuk tanaman yang diberi inokulan BGA dapat terjadi karena BGA dapat mengeluarkan hormon tumbuh. Subba Rao (1994) menjelaskan peran BGA pada tanah sawah selain menambat $\mathrm{N}_{2}$ dari udara dan menyediakannya untuk tanaman, juga mensintesis dan mengekresikan beberapa vitamin dan zat tumbuh (vitamin $\mathrm{B}_{12}$, auksin, asam giberelat dan asam askorbat) yang menyebabkan pertumbuhan tanaman terutama bagian pupus meningkat.

\subsection{Bobot Kering Tajuk Tanaman Padi}

Interaksi antara inokulasi BGA dengan pupuk $\mathrm{N}$ berpengaruh nyata terhadap bobot kering tajuk tanaman padi (Tabel 3). Interaksi antara inokulasi Blue-green algae dan pupuk $\mathrm{N}$ terhadap bobot kering pupus berdeda nyata karena masing-masing faktor dapat mempengaruhi pertumbuhan tajuk tanaman padi sehingga kombinasi perlakuan memberikan pengaruh yang nyata dalam meningkatkan bobot kering tajuk. Interaksi yang diikuti dengan peningkatan bobot kering tajuk akan terjadi apabila BGA dapat beraktivitas dengan baik sehingga pengaruhnya terhadap bobot kering pupus akan nyata pada berbagai taraf pupuk $\mathrm{N}$.

Terdapat pengaruh yang nyata antara pupuk $\mathrm{N} 60 \mathrm{~kg} \mathrm{~N}^{-1}$ dengan inokulan BGA 5 kg ha-1 dalam meningkatkan bobot kering tajuk tanaman padi. Demikian pula apabila

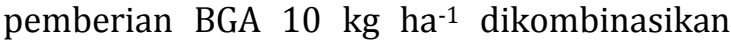
dengan $90 \mathrm{~kg} \mathrm{~N}^{-1}$ akan menghasilkan bobot kering tajuk tanaman yang tinggi. Hal tersebut memperlihatkan perbedaan bobot kering tajuk yang tidak meningkat dengan perlakuan dengan dosis BGA yang sama dikombinasikan dengan dosis $\mathrm{N}$ anjuran yaitu $120 \mathrm{~kg} \mathrm{~N} \mathrm{ha}^{-1}$. Pengurangan dosis pupuk $\mathrm{N}$ dikombinasikan dengan pemberian inokulan BGA terbukti dapat meningkatkan bobot kering tajuk tanaman padi dan hasilnya tidak berbeda dengan pemberian pupuk $\mathrm{N}$ sesuai dosis anjuran $120 \mathrm{~kg} \mathrm{~N}^{-1}$ hanpa inokulan BGA. Nilsson et. al. (2002) melaporkan bahwa pemberian nitrogen yang mengandung amonia dapat menghambat sintesis enzim nitrogenase dan pembentukan sel heterokis Sianobakteri. Pemberian pupuk nitrogen yang mengandung nitrat atau ammonium di tanah sawah juga dapat menghambat aktivitas penambatan nitrogen oleh Cyanobakteri.

Tabel 3 Pengaruh inokulasi BGA dan pupuk $\mathrm{N}$ terhadap bobot kering tajuk tanaman padi (g/rumpun)

\begin{tabular}{|c|c|c|c|}
\hline \multirow{2}{*}{$\begin{array}{l}\text { Pupuk } \\
\text { Nitrogen }\end{array}$} & \multicolumn{3}{|c|}{ BGA } \\
\hline & $\begin{array}{l}\text { kontrol } \\
\left(\mathrm{k}_{0}\right)\end{array}$ & $\begin{array}{c}5 \mathrm{~kg} \mathrm{ha}^{-1} \\
\left(\mathrm{k}_{1}\right)\end{array}$ & $\left(\mathrm{k}_{2}\right)$ \\
\hline $\begin{array}{c}30 \mathrm{~kg} \mathrm{~N} \mathrm{ha}^{-1} \\
\left(\mathrm{n}_{1}\right)\end{array}$ & $\begin{array}{c}.367 \mathrm{a} \\
\mathrm{A}\end{array}$ & $\begin{array}{c}53.460 \mathrm{ab} \\
\mathrm{B}\end{array}$ & $\begin{array}{c}52.05 / \mathrm{d} \\
\mathrm{B}\end{array}$ \\
\hline $\begin{array}{c}60 \mathrm{~kg} \mathrm{~N} \mathrm{ha}-1 \\
\left(\mathrm{n}_{2}\right)\end{array}$ & $\begin{array}{c}50.950 \mathrm{a} \\
\mathrm{A}\end{array}$ & $\begin{array}{c}65.037 \mathrm{~b} \\
\mathrm{~B}\end{array}$ & $\begin{array}{c}53.437 \mathrm{a} \\
\mathrm{AB}\end{array}$ \\
\hline $\begin{array}{c}90 \mathrm{~kg} \mathrm{~N} \mathrm{ha-1} \\
\left(\mathrm{n}_{3}\right)\end{array}$ & $\begin{array}{c}57.170 \\
\mathrm{~A}\end{array}$ & $\begin{array}{c}48.733 \mathrm{a} \\
\mathrm{A}\end{array}$ & $\begin{array}{c}60.623 \mathrm{~b} \\
\mathrm{~B}\end{array}$ \\
\hline $\begin{array}{c}120 \mathrm{~kg} \mathrm{~N} \mathrm{ha}^{-1} \\
\left(\mathrm{n}_{4}\right)\end{array}$ & $\begin{array}{c}60.570 \mathrm{~b} \\
\mathrm{~B}\end{array}$ & $\begin{array}{c}48.700 \mathrm{a} \\
\mathrm{A}\end{array}$ & $\begin{array}{c}55.513 \mathrm{a} \\
\mathrm{A}\end{array}$ \\
\hline \multicolumn{4}{|c|}{$\begin{aligned} \text { Keterangan : } & \text { Angka-angka yang diikuti huruf yang } \\
& \text { sama tidak berbeda nyata menurut uji } \\
& \text { Jarak Berganda Duncan pada taraf } 5 \%, \\
& \text { angka yang ditandai huruf kapital } \\
& \text { dibaca horizontal dan huruf kecil dibaca } \\
& \text { vertikal. }\end{aligned}$} \\
\hline
\end{tabular}

\subsection{Hasil (Bobot Kering Gabah)}

Interaksi terjadi antara inokulasi BGA dengan pupuk $\mathrm{N}$ terhadap peningkatan hasil padi sawah. Bobot kering gabah yang tertinggi dicapai dari pemberian inokulan BGA $10 \mathrm{~kg}$ $\mathrm{ha}^{-1}$ dengan $90 \mathrm{~kg} \mathrm{~N}$ ha $^{-1}$ pupuk $\mathrm{N}$, dan hasilnya lebih tinggi dari pada penggunaan pupuk $\mathrm{N}$ dosis anjuran $120 \mathrm{~kg} \mathrm{~N}^{-1}$ tanpa maupun diberi inokulan BGA $10 \mathrm{~kg} \mathrm{ha}^{-1}$. Dengan mengurangi dosis pupuk $\mathrm{N}$ sebesar 30 $\mathrm{kg} \mathrm{N} \mathrm{Na}^{-1}$ dan diberi inokulan BGA $10 \mathrm{~kg} \mathrm{ha}^{-1}$ menghasilkan peningkatan bobot gabah kering panen sebesar 21,23 g per pot dibandingkan dengan tanaman padi yang diberi pupuk $120 \mathrm{~kg} \mathrm{~N}^{-1}$. Peningkatan hasil bobot gabah kering padi dengan mengurangi dosis pupuk urea menjadi $90 \mathrm{~kg} \mathrm{~N}^{-1}$ akan tetapi menambah inokulan BGA sebesar $10 \mathrm{~kg}$ ha $^{-1}$ akan meningkatkan hasil sebesar 31,52 \% gabah kering panen (GKP). 
Tabel 4 Pengaruh inokulasi BGA dan pupuk $\mathrm{N}$ terhadap bobot kering gabah $(g)$

\begin{tabular}{|c|c|c|c|}
\hline \multirow{2}{*}{$\begin{array}{l}\text { Pupuk } \\
\text { Nitrogen }\end{array}$} & \multicolumn{3}{|c|}{ BGA } \\
\hline & $\begin{array}{c}\text { kontrol } \\
\left(\mathrm{k}_{0}\right)\end{array}$ & $\begin{array}{c}5 \mathrm{~kg} \mathrm{ha}^{-1} \\
\left(\mathrm{k}_{1}\right)\end{array}$ & $\begin{array}{c}10 \mathrm{~kg} \mathrm{ha}^{-1} \\
\left(\mathrm{k}_{2}\right)\end{array}$ \\
\hline \multirow{2}{*}{$\begin{array}{l}30 \mathrm{~kg} \mathrm{~N} \mathrm{ha}^{-1} \\
\quad\left(\mathrm{n}_{1}\right)\end{array}$} & & $\mathrm{a}$ & $52.4 \mathrm{C}$ \\
\hline & A & B & $A$ \\
\hline \multirow{2}{*}{$\begin{array}{l}60 \mathrm{~kg} \mathrm{~N} \mathrm{ha}^{-1} \\
\quad\left(\mathrm{n}_{2}\right)\end{array}$} & $62.117 \mathrm{ab}$ & $65.657 \mathrm{a}$ & 73.590 \\
\hline & A & A & $\mathrm{P}$ \\
\hline \multirow{2}{*}{$\begin{array}{c}90 \mathrm{~kg} \mathrm{~N} \mathrm{ha}^{-1} \\
\left(\mathrm{n}_{3}\right)\end{array}$} & $66.223 \mathrm{~b}$ & $70.323 \mathrm{~b}$ & $88.573 \mathrm{c}$ \\
\hline & A & $\mathrm{AB}$ & B \\
\hline \multirow{2}{*}{$\begin{array}{c}120 \underset{\mathrm{kg} \mathrm{N}}{\left(\mathrm{n}_{4}\right)} \\
0 \mathrm{ha}^{-1}\end{array}$} & $67.343 \mathrm{~b}$ & $73.910 \mathrm{~b}$ & 74.287 \\
\hline & A & B & B \\
\hline \multicolumn{4}{|c|}{$\begin{array}{l}\text { an : Angka-angka yang diikuti huruf yang } \\
\text { sama tidak berbeda nyata menurut uj } \\
\text { Jarak Berganda Duncan pada taraf } 5 \% \\
\text { angka yang ditandai huruf kapita } \\
\text { dibaca horizontal dan huruf keci } \\
\text { dibaca vertikal. }\end{array}$} \\
\hline
\end{tabular}

Bila hasil padi sawah hasil penelitian dikonversikan ke dalam hektar yang didalamnya terdapat tanaman padi sebanyak 160.000 tanaman dengan efisiensi lahan sebesar $80 \%$ maka peningkatan hasil perlakuan $\mathrm{n}_{3} \mathrm{k}_{2}$ perhektar dapat meningkat sebesar 2.71 ton ha-1. Hal ini menggambarkan bahwa pemberian inokulan BGA dapat menjadi alternatif pengurangan dosis pupuk $\mathrm{N}$ untuk padi sawah sekaligus dapat meningkatkan hasil lebih besar dari pada hasil padi sawah dengan menggunakan dosis pupuk $\mathrm{N}$ sesuai anjuran Deptan $120 \mathrm{~kg} \mathrm{~N} \mathrm{ha-1.}$ Peningkatan hasil padi pada penelitian ini dicapai pada pemberian pupuk $\mathrm{N} 90 \mathrm{~kg} \mathrm{~N}^{\mathrm{N}} \mathrm{h}^{-1}$ dengan inokulan BGA sebesar $10 \mathrm{~kg} \mathrm{ha}^{-1}$, sehingga pemberian inokulan BGA dapat menghemat penggunaan pupuk NN (urea) sebesar $25 \%$ dengan hasinnya meningkat sebesar $31,47 \%$.

Penambahan inokulan BGA sebesar $10 \mathrm{~kg}$ ha ${ }^{-1}$ pada tanaman padi yang diberi pupuk $\mathrm{N}$ sebesar $120 \mathrm{~kg} \quad \mathrm{~N} \quad \mathrm{ha}^{-1}$ tidak dapat meningkatkan hasil dibandingkan dengan pemberian inokulan BGA sebesar $10 \mathrm{~kg}^{\mathrm{h}} \mathrm{a}^{-1}$ dengan $120 \mathrm{~kg} \mathrm{~N} \mathrm{ha}^{-1}$, akan tetapi justru menurunkan hasil. Hal tersebut diduga disebabkan aktivitas BGA yang terhambat dalam menambat $\mathrm{N}_{2}$ dikarenakan tingginya suplai $\mathrm{N}$ di dalam tanah akibat pemberian pupuk urea. Pendapat ini didukung oleh Jha et. al. (2001) yang menyatakan dosis pupuk yang tinggi terbukti menghambat cyanobacteria penambat nitrogen yang mengindikasikan bahwa penggunaan pupuk kimia secara tidak terkendali untuk jangka waktu yang lama secara drastis mengganggu keseimbangan ekologis alami. Ghosh and Saha (1993) menambahkan inokulasi sianobakteri dapat meningkatkan hasil gabah dan jerami tanaman padi pada saat pupuk $\mathrm{N}$ tidak diberikan. Hasil gabah dan jerami secara signifikan berkorelasi dengan aktivitas reduksi asetilena di tanah tergenang dan pada sistem perakaran selama fase anakan dan pertumbuhan anakan maksimum.

\section{KESIMPULAN}

Berdasarkan hasil penelitian dapat disimpulkan bahwa:

1. Penggunaan BGA dapat meningkatkan laju pertumbuhan tanaman padi dan dapat mengurangi kebutuhan urea sebesar $25 \%$.

2. Kombinasi pupuk $\mathrm{N} 90 \mathrm{~kg} \mathrm{ha}^{-1}$ dengan inokulan Blue-green algae $10 \mathrm{~kg} \mathrm{ha}^{-1}$ dapat meningkatkan hasil gabah sebesar $31,47 \%$ per hektar $(2,71$ ton ha-1).

\section{DAFTAR PUSTAKA}

Chakdar, H., S.D. Jadhav, D.W. Dhar, and S. Pabbi. 2012. Potential applications of blue green algae. Journal of Scientific and Industrial Research 71(1): 13-20.

Dawe, D. 2000. The potential role of biological nitrogen fixation in meeting future demand for rice and fertilizer. In J.K. Ladha, and P.M. Reddy (eds.). Nitrogen Fixation in Rice. International Rice Research Instutute, Los Banos. pp 110. 
De Datta, S.K. 1975. Upland rice around the world. In International Rice Risearch Institute (Ed) Major Research in Upland Rice. IRRI, Los Banos. pp 1-11.

Donahue, R.L., R.W. Miller, and J.C. Shickluna. 1983. Soils, An Introduction to Soil and Plant Growth. 5th ed. Prentice Hall, Inc., Englewood Cliffs, NJ.

Gardner, F.P., R.B. Pearce, dan R.L. Mitchell, 2008. Fisiologi Tanaman Budidaya. Diterjemahkan oleh: Susilo, H dan Subiyanto. UI-Press. Jakarta.

Ghosh T.K. and K.C Saha. 1993. Effects of inoculation with $\mathrm{N}_{2}$-fixing cyanobacteria on the nitrogenase activity in soil and rhizosphere of wetland rice (Oryza sativa l.). Biology and Fertility of Soils, 16 (1): 16-20.

Goyal S.K. 1993. Algal biofertilizer for vital soil and free nitrogen. Proc Ind Natl Sci Acad 3 \& 4: 295-302.

Giller, K. E., 2001. Nitrogen Fixation in Tropical Cropping Systems 2nd Edition. CABI Publishing series. New York, USA.

Jha, M.N., A.N. Prasad, S.G. Sharma, and R.C. Bharati. 2001. Effects of fertilization rate and crop rotation on diazotrophic cyanobacteria in paddy field. World Journal of Microbiology and Biotechnology, 17 (5): 463-468.

Jipelos, M. J. 1989. Uptake of Nitrogen from urea fertilizer for rice and oil palm. In J. Var der Heide Nutrient (Ed.) Management for Food Crops Production in Tropical Farming System. Institute for SoilFertility (IB) haren, The Netherland. pp 187 - 204.

Kaushik, B.D. 2014. Developments in Cyanobacterial biofertilizer. Proceedings Indian Natural Science Academy 80 (2): $379-388$
Misra S and Kaushik B.D. 1989. Growth promoting substances of cyanobacteria I. Vitamins and their influence on rice plant. Proceedings of Indian National Science Academy B 55: 499-504.

Nilsson, M., J. Bhattacharya, A.N. Rai and B. Bergman. 2002. Colonization of roots of rice (Oryza sativa L.) by symbiotic Nostoc strains. New Phytologist. 156 (3): 517-525.

Novizan. 2003. Petunjuk Pemupukan yang Efektif. AgroMedia Pustaka. Jakarta.

Oren, A. 2004. A proposal for further integration of the cyanobacteria under the Bacteriological Code. Int. J. Syst. Evol. Microbiol. 54 (Pt 5): 1895- 1902.

Roger, P.A. arid S.A. Kulasooriya. 1980. Bluegreen Algae and Rice. The International Rice Research Institute, Manila.

Roger P.A., W.J. Zimmerman, and T.A. Lumpkin. 1993. Microbiological management of wetland rice fields. In Metting, F.B (Ed.) Soil Microbial Ecology: Applications in Agricultural and Environmental Management. Marcel Dekker, New York. pp: 417455.

Stoltzfus J.R., R. So, P.P. Malarvithi, J.K. Ladha, F.J.de Bruijn. 1997. Isolation of endophytic bacteria from rice and assessment of their potential for supplying rice with biologically fixed nitrogen. Plant and Soil, 194(1-2): 2536.

Rao, N.S.S. 1994. Biofertilizer in Agriculture. Oxford \& IBH Publishing Co. New Delhi. 